\title{
PEMANFAATAN PANAS BUANG BOILER MINI MENJADI LISTRIK DENGAN MENGGUNAKAN PELTIER ELEMENT (PE)
}

\section{The Use of Waste Heat Mini Boiler into Electricity Using Peltier Element (PE)}

\section{Klisman Lumban Batu${ }^{1}$, Yudi Dermawan ${ }^{1}$ dan Istianto Budhi Rahardja ${ }^{1 *}$}

${ }^{1}$ Politeknik Kelapa Sawit Citra Widya Edukasi, Teknologi Pengolahan Hasil Perkebunan, Jalan Gapura No.8, Rawa Banteng, Cibuntu, Cibitung, Bekasi, Jawa Barat 17520, Indonesia

Informasi artikel

Diterima: $19 / 01 / 2020$ Direvisi : 21/01/2020 Disetujui: 22/01/2020

\begin{abstract}
Abstrak
Thermoelektrik adalah Teknologi yang bekerja dengan mengkonversi energi panas menjadi energi listrik secara langsung. Pembangkit Thermoelektrik bekerja berdasarkan efek seebeck dimana jika terdapat dua buah material atau lempeng logam yang tersambung pada lingkungan dengan suhu yang berbeda maka akan menimbulkan aliran arus listrik didalam material tersebut. Penelitian ini bertujuan untuk memanfaatkan panas buangan menjadi aliran listrik dengan menggunakan silencer knalpot, 2 buah elemen Peltier TEG SP1848 21745 SA, dan boiler mini sebagai sumber panas pengujian alat. Hasil pengujian menunjukkan bahwa dengan 2 buah elemen Peltier TEG SP1848 21745 SA yang disusun secara pararel menghasilkan arus maksimum 35,7 mA dan temperatur berbanding lurus dengan aliran arus listrik dan dapat dinyatakan dalam analogi aliran listrik Hukum Ohm II dimana $\mathrm{I}=\frac{\mathrm{V}}{\mathrm{R}} \cong \mathrm{q}=$ $\frac{\Delta \mathrm{T}}{\mathrm{R}_{\text {total }}}$. Metode Penelitian yang dilakukan dengan metode eksperimental. Pengujian dilakukan di Workshop Politeknik Kelapa Sawit Citra Widya Edukasi dengan waktu pengujian selama 10 menit dan pengambilan data setiap 1 menit.
\end{abstract}

Kata Kunci: thermoelektrik, elemen peltier, analogi aliran listrik.

\begin{abstract}
Thermoelektrik is a technology that is working with a convert of energy heat to become the electrics energy directly. The operation of its thermoelektrik works based on the effect of seebeck where is if there are two pieces of material or of a plate of metal connected at the environment to the different temperatures it will cause the flow of electrical current stood up in the paper the materials. This research intended to capitalize on the of waste heat to the flow of electricity by using silencer exhaust, 2 the fruit of the Element Peltier TEG SP1848 21745 one offender exceeds another $i$, and of the boilers of mini as the source of heat testing an instrument. The results of the testing showed that with 2 the fruit of the element Peltier TEG SP 184821745 one offender exceeds another $i$ which are drawn up so in parallel produces a current of up to a maximum of $35,7 \mathrm{~mA}$ and wide range of temperatures is directly proportional to the flow of an electric current and the can be expressed in the analogy of a flow of electricity Law Ohm II where he deprecated sweeping and unjust $I=\frac{V}{R} \cong q=\frac{\Delta T}{R_{\text {total }}}$. A method of research conducted with the experimental methods. Testing was done in the workshop Polytechnic Palm Oil Citra Widya Education with time testing for 10 minutes and data retrieval 1 every minutes.
\end{abstract}

Keywords: thermoelektrik, peltier elements, the analogy of the flow of electricity.

*Penulis Korespondensi. Tel: 021-29091337; Handphone: 081286372761 


\section{PENDAHULUAN}

Listrik merupakan suatu muatan-muatan bergantung pada kedudukan relatifnya serta kecepatan yang dimiliki akibat gaya listrik dan gaya magnet. Listrik sangat penting untuk kehidupan manusia, hal itu digunakan baik dalam penerangan ruangan, sumber energi dari beberapa alat elektronik rumah tangga salah satu contohnya adalah handphone. Listrik tersebut dihasilkan dari sebuah alat yang berskala besar yaitu pembangkit listrik kemudian dapat disalurkan dan digunakan oleh masyarakat. Sebuah pembangkit listrik untuk menghasilkan listrik memerlukan suatu sumber kemudian sumber tersebut digunakan sebagai tenaga pembangkitnya seperti tenaga air (PLTA), tenaga uap (PLTU), tenaga diesel (PLTD), tenaga gas (PLTG), tenaga panas bumi (PLTP) serta tenaga nuklir (PLTN).

Pembangkit listrik yang memanfaatkan energi panas, tidak semua energi panas dapat diubah menjadi energi listrik. Hal tersebut juga terjadi di pabrik kelapa sawit yang memanfaatkan panas untuk mengolah TBS menjadi CPO akan tetapi masih banyak panas yang terbuang ke lingkungan baik dalam bentuk uap atau limbah cair salah satu contohnya adalah di stasiun sterilizer ataupun di stasiun press. Hal tersebut dapat diatasi menggunakan teknologi thermoelektrik dimana panas buangan tersebut diubah menjadi energi listrik dengan tujuan energi panas tersebut tidak terbuang sia-sia ke lingkungan. Menurut Ryanuargo dkk. (Ryanuargo, 2013), pemanfaatan pembangkit thermoeletrik ini ramah lingkungan karena tidak menimbulkan polusi terhadap lingkungan. pemanfaatan lain yang dipergunakan dalam perkebunan kedelai, dapat memanipulasi suhu dan kelembaban (Khamid, 2015).

Pada tahun 1821 Thomas Johann Seebeck pertama kali menemukan modul thermoelectric yang bekerja berdasarkan prinsip dari efek seebeck yaitu bila terdapat dua material yang berbeda dan pada temperatur yang berbeda kemudian disambungkan maka akan mengalir arus listrik dan akan terlihat perbedaan tegangan apabila dihubungkan dengan galvanometer. Dalam prinsip thermoelektric besarnya tegangan listrik yang dihasilkan sebanding dengan dengan gradien suhu. Dalam sebuah penelitian yang telah dilakukan Putra dkk. (Putra et al., 2009), telah menstimulasikan sebuah pemanas atau heater yang divariasikan tegangannya, yaitu $110 \mathrm{~V}$ dan 220 V. Hasil penelitian menunjukkan bahwa dengan 12 elemen thermoelectric yang disusun secara seri dengan tegangan pemanas $220 \mathrm{~V}$, dapat menghasilkan daya output maksimum 8,11 $\mathrm{W}$ dengan perbedaan temperatur rata rata $42,820 \mathrm{C}$.

Penelitian ini diharapkan menjadi salah satu solusi untuk memanfaatkan banyaknya energi panas yang terbuang di pabrik kelapa sawit kemudian dapat dikembangkan menjadi salah satu sumber energi listrik alternatif untuk diproduksi, disalurkan dan digunakan oleh masyarakat dalam kehidupan sehari hari.

\section{TEORI DASAR}

\section{Thermoelectric}

Pembangkit thermoelectric bekerja berdasarkan efek seebeck dimana jika terdapat dua buah material atau lempeng logam yang tersambung pada lingkungan dengan suhu yang berbeda maka akan menimbulkan aliran arus listrik di dalam material tersebut.

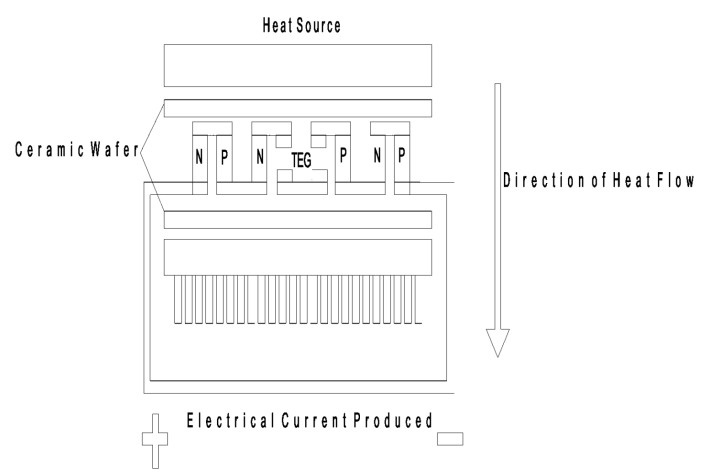

Gambar 1 Struktur pembangkit daya termoelektrik (Putra et al., 2009)

Gambar 1. menunjukkan struktur TEG yang terdiri dari suatu susunan elemen tipe-n (material dengan kelebihan elektron) dan tipe-p (material dengan kekurangan elektron). Panas masuk pada satu sisi dan dibuang dari sisi yang lainya, menghasilkan suatu tegangan yang melewati sambungan termoelektrik.

Besarnya tegangan yang dihasilkan sebanding dengan gradien temperatur. Modul termoelektrik adalah sirkuit terintegrasi dalam bentuk solid yang menggunakan tiga prinsip termodinamika yang dikenal sebagai efek Seebeck, Peltier dan Thompson. Konstruksinya terdiri dari pasangan material semikonduktor tipe-p dan tipe-n yang membentuk termokopel yang memiliki 
bentuk seperti sandwich hantar dua wafer keramik tipis. Modul ini dapat digunakan untuk menghasilkan panas dan dingin di masing-masing sisinya jika arus listrik digunakan biasanya diaplikasikan sebagai sistem pendingin. Heatsink digunakan untuk membantu meningkatkan pelepasan kalor pada sisi dingin sehingga meningkatkan efisiensi dari modul tersebut. Potensi pembangkitan dari daya modul thermoelektrik akan berbeda-beda pada ukuran, konstruksi, dan perbedaan temperaturnya. Perbedaan yang makin besar antara sisi panas dan sisi dingin modul akan menghasilkan tegangan dan arus yang lebih besar (Salsabiila et al., 2019).

\section{Sistem Konversi Energi Panas dengan Termoelektrik}

Perpindahan panas terjadi di antara material/benda karena adanya perbedaan suhu ( panas dan dingin ) dimana panas akan mengalir dari tempat yang suhunya tinggi menuju tempat yang suhunya lebih rendah. Perpindahan panas terjadi dengan beberapa proses perpindahan panas yaitu konduksi, konveksi, dan radiasi (Buchori, 2004)

\section{Perpindahan Panas Konduksi}

Konduksi adalah proses perpindahan panas yang terjadi pada benda solid dan panas mengalir dari tempat yang suhunya tinggi ke tempat yang suhunya lebih rendah. Dasar Hukum Fourier (Prijono, 1997) :

$$
\mathrm{q}_{\mathrm{k}}=\mathrm{kA}\left(-\frac{\mathrm{dT}}{\mathrm{dX}}\right) \text { atau } \frac{\mathrm{q}_{\mathrm{k}}}{\mathrm{A}}=\mathrm{k}\left(-\frac{\mathrm{dT}}{\mathrm{dX}}\right)
$$

Perpindahan panas dinyatakan dengan analogi aliran listrik ( Hukum Ohm II )

$$
\begin{aligned}
& \text { Aliran Listrik }=\frac{\text { Potensial }}{\text { Tahanan }} \\
& \mathrm{I}=\frac{\mathrm{V}}{\mathrm{R}_{\mathrm{e}}} \cong \mathrm{q}=\frac{\Delta \mathrm{T}}{\mathrm{R}}=\frac{T 1-T 2}{\frac{\Delta x}{k A}}
\end{aligned}
$$

dimana :

$\mathrm{q}=$ Laju Perpindahan Panas (Watt)

$\mathrm{I}=$ Aliran Listrik (Ampere )

$\Delta \mathrm{T}=$ Selisih Temperatur $\left({ }^{\circ} \mathrm{C}\right)$

$\mathrm{T} 1=$ Temperatur Awal $\left({ }^{\circ} \mathrm{C}\right)$

$\mathrm{T} 2=$ Temperatur Akhir $\left({ }^{\circ} \mathrm{C}\right)$

$\mathrm{V}=$ Potensial $(\mathrm{v})$

$\mathrm{R}_{\mathrm{e}}=$ Tahanan Listrik $(\mathrm{Ohm})$

$\mathrm{R}=$ Tahanan Termal $\left({ }^{\circ} \mathrm{C} / \mathrm{W}\right)$

$\mathrm{x}=$ Tebal Bahan $(\mathrm{m})$
$\mathrm{K}=$ Konduktivitas Termal Bahan $\left(\mathrm{W} / \mathrm{m}^{\circ} \mathrm{C}\right)$

Perpindahan panas pada bidang datar:

$$
q=\frac{\Delta T}{R}=\frac{T 1-T 2}{\frac{\Delta x}{k A}}
$$

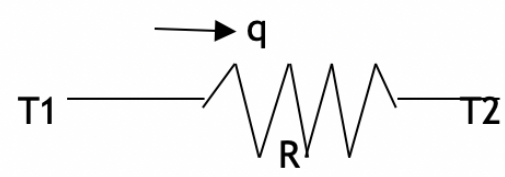

Gambar 2 Diagram resistance

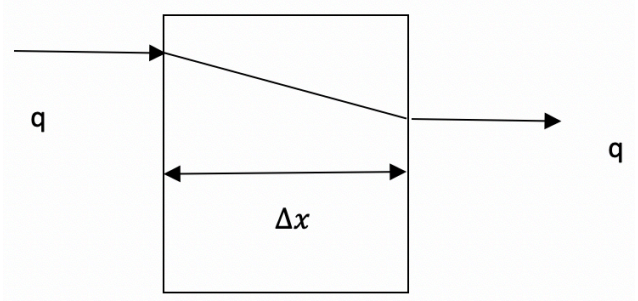

Gambar 3 Perpindahan panas pada plat datar

$\mathrm{q}=$ Laju Perpindahan Panas (Watt)

$\Delta \mathrm{T}=$ Selisih Temperatur $\left({ }^{\circ} \mathrm{C}\right)$

$\mathrm{T} 1=$ Temperatur Awal $\left({ }^{\circ} \mathrm{C}\right)$

$\mathrm{T} 2=$ Temperatur Akhir $\left({ }^{\circ} \mathrm{C}\right)$

$\mathrm{R}=$ Tahanan Termal $\left({ }^{\circ} \mathrm{C} / \mathrm{W}\right)$

$\mathrm{x}=$ Tebal Bahan $(\mathrm{m})$

$\mathrm{K}=$ Konduktivitas Termal Bahan $\left(\mathrm{W} / \mathrm{m}^{\circ} \mathrm{C}\right)$

\section{Perpindahan Panas pada Silinder Berongga}

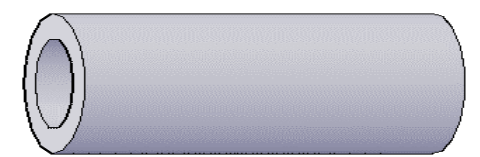

Gambar 4 Silinder Berongga

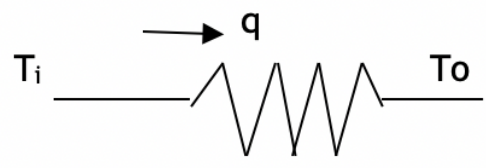

R

Gambar 5 Diagram resistance benda bulat

$$
\mathrm{q}=\frac{\Delta \mathrm{T}}{\mathrm{R}_{\mathrm{th}}}=\frac{\frac{\mathrm{T}_{\mathrm{i}}-\mathrm{T}_{\mathrm{o}}}{\mathrm{In}\left(\frac{\mathrm{r}_{\mathrm{i}}}{\mathrm{r}}\right)}}{\frac{2 \pi \mathrm{kL}}{2}}
$$

$\mathrm{T}_{i=}$ Temperatur dalam $\left({ }^{\circ} \mathrm{C}\right)$

$\mathrm{T}_{o=}$ Temperatur luar $\left({ }^{\circ} \mathrm{C}\right)$

$\mathrm{r}_{\mathrm{i}=\text { Jari jari dalam }(\mathrm{m})}$

$\mathrm{r}_{\mathrm{o}=}$ Jari jari luar $(\mathrm{m})$

$\mathrm{L}=$ Panjang Silinder $(\mathrm{m})$ 
Tabel 1 Konduktivitas Termal Berbagai Zat (Halliday \& Resnick, 1987)

\begin{tabular}{cc}
\hline $\begin{array}{c}\text { Jenis Zat } \\
\left(\mathbf{2 0} \mathbf{~}^{\circ}\right)\end{array}$ & $\begin{array}{c}\text { Konduktivitas } \\
\text { Termal }\left(\mathrm{W} / \mathrm{m} .{ }^{\circ} \mathrm{C}\right)\end{array}$ \\
\hline Aluminium & 200 \\
Kuningan & 110 \\
Tembaga & 390 \\
Timbal & 35 \\
Perak & 410 \\
Besi & 80 \\
Baja & 46 \\
Asbes & 0,008 \\
Beton & 0,80 \\
Gabus & 0,17 \\
Kaca & 0,80 \\
Kayu rata-rata & 0,08 \\
Air & 0,60 \\
Es & 1,70 \\
Udara & 0,024 \\
Hidrogen & 0,14 \\
Oksigen & 0,023 \\
\hline
\end{tabular}

\section{Perpindahan Panas Konveksi}

Konveksi adalah proses transpot dengan kerja gabungan dari konduksi panas, penyimpanan energi dan gerakan mencampur. Konveksi sangat penting sebagai mekanisme perpindahan energi antara permukaan benda padat dan cairan atua gas. Sebuah pelat logam panas akan cepat mendingin jika ditempatkan di depan sebuah kipas angin dibandingkan apabila dibiarkan dalam udara diam. Disebut bahwa panas dikonveksi keluar dan disebut prosesnya perpindahan panas konveksi (Rahardja, 2016).

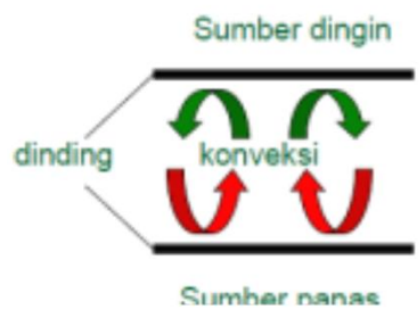

Gambar 6 Proses perpindahan panas konveksi

Laju Perpindahan Panas Konveksi didefenisikan sebagai:

$$
\mathrm{q}_{\mathrm{c}=\mathrm{hA}(\mathrm{Th}-\mathrm{Tc})}
$$

dimana:

$\mathrm{q}=$ Laju Perpindahan Konveksi ( W) $\mathrm{h}=$ Koefisien Proses Konveksi $\left(\mathrm{W} / \mathrm{m}^{2 \circ} \mathrm{C}\right)$

$\mathrm{A}=$ Luas Permukaan $\left(\mathrm{m}^{2}\right)$

$\mathrm{Tc}=$ Temperatur Dingin $\left({ }^{\circ} \mathrm{C}\right)$

$\mathrm{Th}=$ Temperatur Panas $\left({ }^{\circ} \mathrm{C}\right)$

\section{Perpindahan Panas Radiasi}

Perpindahan Panas Radiasi sangan berbeda dengan perpindahan kalor konduksi dimana perpindahan energi terjadi melalui media, maka panas juga bisa dipindahkan melalui vakum. Mekanisme ini disebut dengan radiasi termal.(Rahardja, 2016 )

Dalam thermodinamika, pembangkit panas ideal atau benda hitam akan memancarkan energi sebanding dengan pangkat empat suhu mutlak dan berbanding lurus dengan luas permukaan, atau :

$$
\mathrm{q}_{\mathrm{pancaran}}=\sigma \mathrm{AT}^{4}
$$

dimana:

$\sigma=$ Konstanta Proporsional atau konstanta

Stefan - Boltzma $=5,669 \times 10^{-8} \mathrm{~W} / \mathrm{m}^{2} . \mathrm{K}^{4}$

Energi Radiasi juga dirumuskan dengan :

$$
\mathrm{q}=\mathrm{F \varepsilon F}_{\mathrm{G}} \sigma \mathrm{A}\left(\mathrm{T}_{1}^{4}-\mathrm{T}_{2}^{4}\right)
$$

Dimana:

$\mathrm{F} \varepsilon=$ Fungsi Emisivitas

$\mathrm{F}_{\mathrm{G}}=$ Fungsi faktor pandang geometri

\section{Efek Seebeck}

Salah satu piranti yang menghasilkan energi dari panas adalah elemen Peltier. Pembangkit listrik termal ini atau disebut juga elemen seebeck berbentuk identik dengan elemen peltier. Pada elemen ini efek seebeck dimanfaatkan untuk membangkitkan energi listrik jika terdapat perbedaan suhu pada elemen. Konsep seebeck digambarkan bahwa jika dua buah material logam (biasanya semi konduktor) yang tersambung berada di lingkungan dengan dua temperatur berbeda, maka di material tersebut akan mengalir arus listrik atau gaya gerak listrik. Konsep ini apabila diterapkan pada kendaraan bermotor dengan gas buang pada mesin motor berkisar antara $200-300^{\circ} \mathrm{C}$ dan temperatur lingkungan berkisar antara $30-35^{\circ} \mathrm{C}$, akan menghasilkan gaya gerak listrik yang kemudian dapat digunakan untuk menggerakkan motor listrik atau disimpan di dalam baterai. Apabila dapat diterapkan di kendaraan hibrid, konsumsi bahan bakar pada kendaraan bermotor akan semakin irit (Min, 1994). 


\section{Efek Peltier}

Elemen Peltier atau pendingin termoelektrik (thermoelectric cooler) adalah alat yang dapat menimbulkan perbedaan suhu antara kedua sisinya jika dialiri arus listrik searah pada kedua kutub materialnya, dalam hal ini semikonduktor. Elemen Peltier adalah merupakan bagian terpenting dari generator termoelektrik, kedua sisi yang terbuat dari keramik memiliki fungsi sebagai sisi panas dan sisi dingin yang kemudian menghasilkan arus positif dan negatif(Delly dkk, 2016).

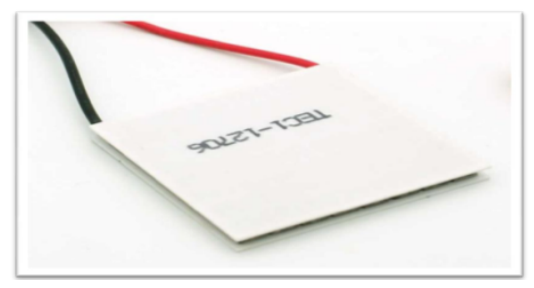

Gambar 7 Element peltier

\section{METODOLOGI}

Pada persiapan awal ditentukan tema dan mencari beberapa literatur yang mendukung dari penelitian yang dilakukan. Selanjutnya merancang/desain (model) untuk sistem panas buang yang akan ditangkap oleh muffler.

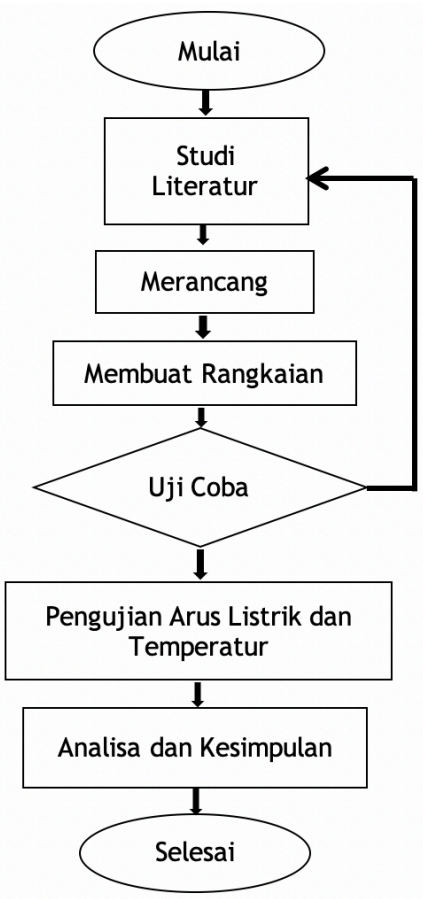

Gambar 8 Diagram alir penelitian
Kemudian muffler dipasang Peltie Element (PE) dan Heatsink dengan perekat dan alat pengukur tegangan dan kuat arus (multitester). Setelah terpasang seluruhnya, maka dilakukan percobaan pemanasan pada muffler dan dilakukan pengambilan data pengujian. Selanjutnya analisa serta kesimpulan hasil pengujian. Berakhir pengujian yang dilakukan. Berikut langkah penelitian yang diperlihatkan pada diagram alir gambar 8 .

\section{HASIL DAN PEMBAHASAN}

\section{Diagram Resistan}

Pengujian alat dilakukan selama 10 menit menggunakan uap panas boiler mini dimana pada saat pengujian boiler bertekanan 1,5 bar atau $\pm 111,37^{\circ} \mathrm{C}$. Pengambilan data dilakukan setiap 1 menit.

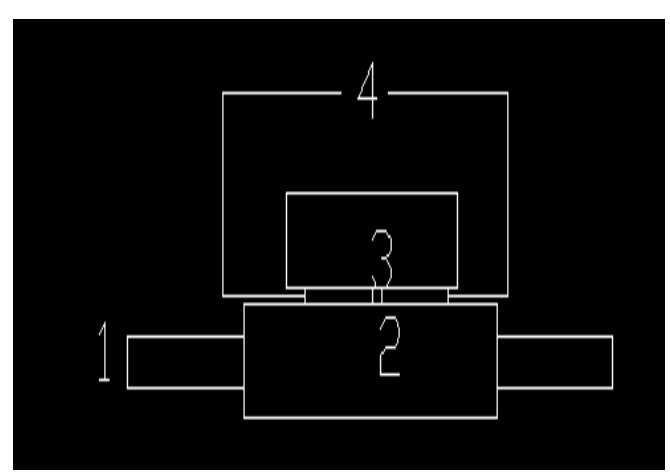

Gambar 9 Sketsa Alat

Keterangan:

$1=$ Inlet Steam

$2=$ Selubung Silencer

$3=$ Heatsink

4=Multitester yang dihubungkan dengan 2 buah peltier (posisi di bawah heatsink).

Diagram Resistan:

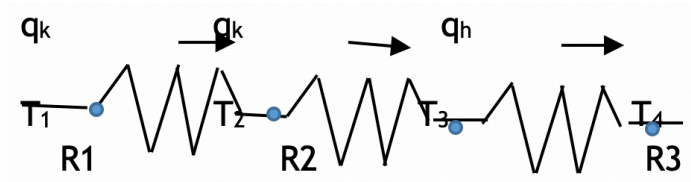

Gambar 9 Diagram alir perpindahan panas

Keterangan:

$\mathrm{T}_{1=}=$ Temperatur Inlet

$\mathrm{T}_{2}=$ Temperatur Selubung

$\mathrm{T}_{3}=$ Temperatur Heatsink

$\mathrm{T}_{4}=$ Temperatur Udara 
Tabel 2 Hasil pengujian alat menggunakan heater uap dari boiler mini

\begin{tabular}{ccccc}
\hline Waktu & $\begin{array}{c}\mathrm{T} 1 \\
\left({ }^{\circ} \mathrm{C}\right)\end{array}$ & $\begin{array}{c}\mathrm{T} 2 \\
\left({ }^{\circ} \mathrm{C}\right)\end{array}$ & $\Delta \mathrm{T}\left({ }^{\circ} \mathrm{C}\right)$ & $\begin{array}{c}\text { Kuat } \\
\text { Arus } \\
\text { Listrik } \\
(\mathrm{mA})\end{array}$ \\
\hline Menit 1 & 37 & 34 & 3 & 5,2 \\
Menit 2 & 42 & 37 & 5 & 6,4 \\
Menit 3 & 49 & 46 & 3 & 7,2 \\
Menit 4 & 58 & 54 & 4 & 7,5 \\
Menit 5 & 61 & 58 & 3 & 7,7 \\
Menit 6 & 64 & 60 & 4 & 12,2 \\
Menit 7 & 72 & 66 & 6 & 19,1 \\
Menit 8 & 75 & 71 & 4 & 25,5 \\
Menit 9 & 78 & 73 & 5 & 30,5 \\
Menit 10 & 85 & 77 & 8 & 35,7 \\
\hline
\end{tabular}

\section{Analisis Perpindahan Panas}

Sistem Thermolektrik menggunakan 2 Peltier TEG SP1848 21745 SA dan ditempelkan tepat diatas silencer knalpot. Peltier TEG SP1848 21745 SA dihubungkan secara pararel dengan Multitester untuk pengukuran kuat arus listrik yang dihasilkan. Pengujian alat dilakukan selama 10 menit menggunakan heater dari uap panas boiler mini dimana pada saat pengujian boiler bertekanan 1,5 bar atau $\pm 111,37^{\circ} \mathrm{C}$. Pengambilan data dilakukan setiap 1 menit.

Panas mengalir dari boiler menuju silencer knalpot. Didalam silencer knalpot terjadi konveksi menuju TEG SP1848 21745 SA dan konduksi menuju heatsink. Arus listrik yang dihasilkan berdasarkan perbedaan temperatur panas dan dingin dari heatsink. Dari analisis hasil dan selama proses pengujian alat sudah bisa menghasilkan arus listrik tetapi masih sangat kecil, hal tersebut dapat dilihat ditabel 2 hasil pengujian alat. Dapat diketahui bahwa kenaikan temperatur sangat mempengaruhi arus listrik yang dihasilkan sistem thermoelektrik tersebut. Pada tabel dapat diperhatikan setiap interval satu menit terjadi kenaikan arus listrik seiring kenaikan temperatur.

Pada alat yang dibuat terjadi proses perpindahan panas konduksi dan konveksi. Konduksi terjadi pada selubung silencer knalpot dan konveksi terjadi pada heatsink. Proses perpindahan dapat dinyatakan dalam analogi listrik ( hukum Ohm II) yaitu $I=\frac{V}{R}$, untuk mengetahui apakah ada pengaruh temperatur terhadap aliran listrik $\Delta T 1=$ $69,37^{\circ} \mathrm{C}, \Delta T 2=3^{\circ} \mathrm{C}, \Delta T 3=4^{\circ} \mathrm{C}, \quad$ Proses perpindahan panas konduksi pada Silinder Berongga terjadi dari dalam silinder menuju keluar silinder $(\Delta T 1)$ dan dari selubung silencer menuju heatsink $(\Delta T 2)$. Pada heatsink terjadi proses konveksi dengan udara luar, dalam proses ini temperatur udara luar dianggap sama dalam 10 menit yaitu $30^{\circ} \mathrm{C}$.

$$
\begin{aligned}
& \mathrm{qk}_{2}=\frac{\Delta \mathrm{T}}{\mathrm{R}_{\mathrm{th}}}=\frac{\mathrm{T}_{\mathrm{i}}-\mathrm{T}_{\mathrm{o}}}{\frac{\operatorname{In}\left(\frac{\mathrm{r}_{\mathrm{i}}}{\mathrm{r}_{\mathrm{o}}}\right)}{2 \pi \mathrm{kL}}} \\
& \mathrm{qk} 1=\frac{\Delta \mathrm{T}}{\frac{\mathrm{x}}{\mathrm{kA}}} \\
& \mathrm{qh}=\mathrm{hA} \Delta \mathrm{T} \\
& r_{i}=0,03 m \\
& \mathrm{x}=0,002 \mathrm{~m} \\
& \mathrm{~A}=0,00624 \mathrm{~m}^{2} \\
& r_{0}=0,0112 \mathrm{~m} \\
& \mathrm{k}=200 \frac{\mathrm{W}}{\mathrm{m} \mathrm{W}^{\circ} \mathrm{C}} \\
& \mathrm{h}=10 \frac{\mathrm{W}}{\mathrm{m}^{2}{ }^{\circ} \mathrm{C}} \\
& \mathrm{T}_{\mathrm{i}}=111,37^{\circ} \mathrm{C} \\
& \mathrm{T}_{0}=37^{\circ} \mathrm{C} \\
& \mathrm{L}=0,275 \mathrm{~m} \\
& \mathrm{q}_{\mathrm{k} 1}=\frac{\Delta \mathrm{T}}{\mathrm{R}}=\frac{74,37^{\circ} \mathrm{C}}{\frac{\mathrm{In} \frac{0,03 \mathrm{~m}}{0,0112 \mathrm{~m}}}{2 \times 3,14 \times 200^{\mathrm{W}} / \mathrm{m}^{\circ} \mathrm{C}}} \\
& \mathrm{q}_{\mathrm{k} 2}=\frac{\Delta \mathrm{T}}{\mathrm{R}}=\frac{0,002 \mathrm{~m}}{200^{\mathrm{W}} / \mathrm{m}^{\circ} \mathrm{C} \times 0,00624 \mathrm{~m}^{2}} \\
& \mathrm{q}_{\mathrm{h}=\frac{\Delta \mathrm{T}}{\mathrm{R}}}=\frac{4^{\circ} \mathrm{C}}{\frac{1}{10^{\mathrm{W}} / \mathrm{m}^{2}{ }^{\circ} \mathrm{C} \times 0,00624 \mathrm{~m}^{2}}} \\
& \mathrm{q}_{\mathrm{k} 1=} \frac{74,37^{\circ} \mathrm{C}}{0,0028525872^{\circ} \mathrm{C} / \mathrm{W}} \\
& \mathrm{q}_{\mathrm{k} 2}=\frac{4^{\circ} \mathrm{C}}{0,0016025641^{\circ} \mathrm{C} / \mathrm{W}} \\
& \mathrm{q}_{\mathrm{h}=\frac{4^{\circ} \mathrm{C}}{16,025641026^{\circ} \mathrm{C} / \mathrm{W}}}
\end{aligned}
$$

Untuk perhitungan selanjutnya $R$ atau hambatan termal tidak berubah sehingga pengaruh kenaikan temperatur pada proses konduksi dan konveksi terhadap aliran listrik terlihat langsung. Aliran listrik

( Hukum Ohm II ) : I $=\frac{\mathrm{V}}{\mathrm{R}}$

Aliran Listrik $=\frac{\text { Potensial }}{\text { Tahanan }}$

$\mathrm{I}=\frac{\mathrm{V}}{\mathrm{R}_{\mathrm{e}}} \cong \mathrm{q}=\frac{\Delta \mathrm{T}}{\mathrm{R}}=\frac{T 1-T 2}{\frac{\Delta x}{k A}}$ 
dimana :

$\mathrm{q}=$ Laju Perpindahan Panas (Watt)

$\mathrm{I}=$ Aliran Listrik (Ampere )

$\Delta \mathrm{T}=$ Selisih Temperatur $\left({ }^{\circ} \mathrm{C}\right)$

$\mathrm{T} 1=$ Temperatur Awal $\left({ }^{\circ} \mathrm{C}\right)$

$\mathrm{T} 2=$ Temperatur Akhir $\left({ }^{\circ} \mathrm{C}\right)$

$\mathrm{V}=\operatorname{Potensial}(\mathrm{v})$

$\mathrm{R}_{\mathrm{e}}=$ Tahanan Listrik (Ohm)

$\mathrm{R}=$ Tahanan Termal $\left({ }^{\circ} \mathrm{C} / \mathrm{W}\right)$

$\mathrm{x}=$ Tebal Bahan $(\mathrm{m})$

$\mathrm{K}=$ Konduktivitas

Termal Bahan $\left(\mathrm{W} / \mathrm{m}^{\circ} \mathrm{C}\right)$

Pada perhitungan q (kalor) yang telah dilakukan, hambatan termalnya tidak berubah sedangkan temperaturnya berbeda beda yang dipengaruhi dari proses konduksi dan konveksi sehingga total kalor yang dihasilkan berbeda beda. Selain karena adanya perbedaan temperatur panas dan dingin, proses kenaikan temperatur berbanding lurus dengan aliran listrik yang dihasilkan. Sesuai dengan analogi listrik Hukum Ohm II $I=\frac{\mathrm{V}}{\mathrm{R}} \cong \frac{\Delta \mathrm{T}}{\mathrm{R}_{\text {total }}}, \quad$ ketika $R_{\text {total }}$ tidak berubah,

$\Delta T$ atau temperatur naik maka I

(aliran arus) dan q ( kalor )juga akan naik.

Tabel 3 Hasil perhitungan kalor konduksi pada bidang silinder selama waktu 10 menit

\begin{tabular}{ccccc}
\hline $\begin{array}{c}\mathrm{T} 1 \\
\left({ }^{\circ} \mathrm{C}\right)\end{array}$ & $\begin{array}{c}\mathrm{T} 2 \\
\left({ }^{\circ} \mathrm{C}\right)\end{array}$ & $\begin{array}{c}\Delta \mathbf{T} \\
\left({ }^{\circ} \mathrm{C}\right)\end{array}$ & $\mathbf{R}\left({ }^{\circ} \mathrm{C} / \mathbf{W}\right)$ & $\begin{array}{c}\mathbf{Q} \\
(\text { Watt })\end{array}$ \\
\hline 111,37 & 37 & 74,37 & 0,002853 & 26071,07 \\
111,37 & 42 & 69,37 & 0,002853 & 24318,28 \\
111,37 & 49 & 62,37 & 0,002853 & 21864,36 \\
111,37 & 58 & 53,37 & 0,002853 & 18709,33 \\
111,37 & 61 & 50,37 & 0,002853 & 17657,65 \\
111,37 & 64 & 47,37 & 0,002853 & 16605,98 \\
111,37 & 72 & 39,37 & 0,002853 & 13801,51 \\
111,37 & 75 & 36,37 & 0,002853 & 12749,83 \\
111,37 & 78 & 33,37 & 0,002853 & 11698,15 \\
111,37 & 85 & 26,37 & 0,002853 & 9244,24 \\
\hline
\end{tabular}

Dari gambar 10, dapat dilihat $\mathrm{R}^{2}=1$, ada hubungan kuat antara $\Delta \mathrm{T}$ atau selisih temperatur terhadap Kalor yang dihasilkan. Dimana ketika ada penurunan selisih temperatur maka kalornya yang dihasilkan juga menurun.

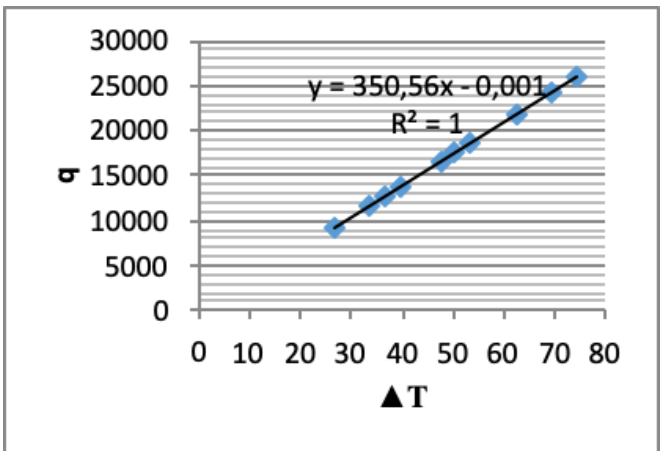

Gambar 10 Hubungan Temperatur terhadap Kalor

Tabel 4 Hasil perhitungan kalor konduksi pada heatsink selama waktu 10 menit

\begin{tabular}{ccccc}
\hline $\begin{array}{c}\mathrm{T} 2 \\
\left({ }^{\circ} \mathrm{C}\right)\end{array}$ & $\begin{array}{c}\mathrm{T} 3 \\
\left({ }^{\circ} \mathrm{C}\right)\end{array}$ & $\begin{array}{c}\Delta \mathrm{T} \\
\left({ }^{\circ} \mathrm{C}\right)\end{array}$ & $\mathrm{R}\left({ }^{\circ} \mathrm{C} / \mathbf{W}\right)$ & $\begin{array}{c}\mathrm{q} \\
(\mathrm{Wat})\end{array}$ \\
\hline 37 & 34 & 3 & 0,001603 & 1872 \\
42 & 37 & 5 & 0,001603 & 3120 \\
49 & 46 & 3 & 0,001603 & 1872 \\
58 & 54 & 4 & 0,001603 & 2496 \\
61 & 58 & 3 & 0,001603 & 1872 \\
64 & 60 & 4 & 0,001603 & 2496 \\
72 & 66 & 6 & 0,001603 & 3744 \\
75 & 71 & 4 & 0,001603 & 2496 \\
78 & 73 & 5 & 0,001603 & 3120 \\
85 & 77 & 8 & 0,001603 & 4992 \\
\hline
\end{tabular}

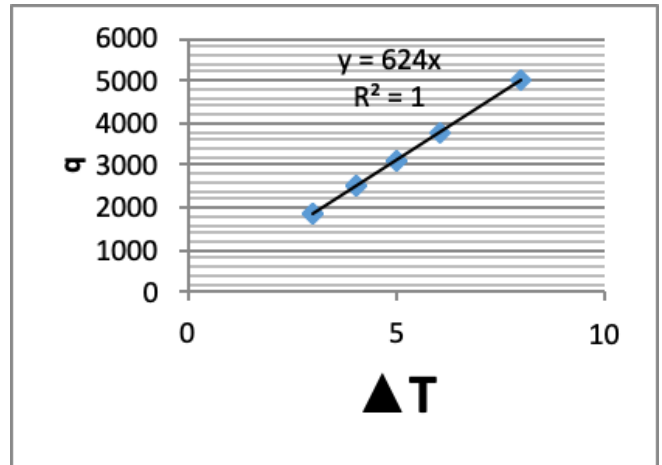

Gambar 11 Hubungan temperatur terhadap kalor

Dari gambar 11 , dapat dilihat $R^{2}=1$, ada hubungan kuat antara $\Delta \mathrm{T}$ atau selisih temperatur terhadap Kalor yang dihasilkan. Semakin naik $\Delta \mathrm{T}$ maka kalor yang dihasilkan juga akan naik. 
Tabel 5 Hasil perhitungan total kalor konveksi pada heatsink selama waktu 10 menit

\begin{tabular}{ccccc}
\hline $\begin{array}{c}\mathrm{T} 3 \\
\left({ }^{\circ} \mathrm{C}\right)\end{array}$ & $\begin{array}{c}\mathrm{T} 4 \\
\left({ }^{\circ} \mathrm{C}\right)\end{array}$ & $\begin{array}{c}\Delta \mathrm{T} \\
\left({ }^{\circ} \mathrm{C}\right)\end{array}$ & $\begin{array}{c}\mathrm{R} \\
\left({ }^{\circ} \mathrm{C} / \mathrm{W}\right)\end{array}$ & $\begin{array}{c}\mathrm{q} \\
(\text { Watt })\end{array}$ \\
\hline 34 & 30 & 4 & 16,02564 & 0,2496 \\
37 & 30 & 7 & 16,02564 & 0,4368 \\
46 & 30 & 16 & 16,02564 & 0,9984 \\
54 & 30 & 24 & 16,02564 & 1,4976 \\
58 & 30 & 28 & 16,02564 & 1,7472 \\
60 & 30 & 30 & 16,02564 & 1,872 \\
66 & 30 & 36 & 16,02564 & 2,2464 \\
71 & 30 & 41 & 16,02564 & 2,5584 \\
73 & 30 & 43 & 16,02564 & 2,6832 \\
77 & 30 & 47 & 16,02564 & 2,9328 \\
\hline
\end{tabular}

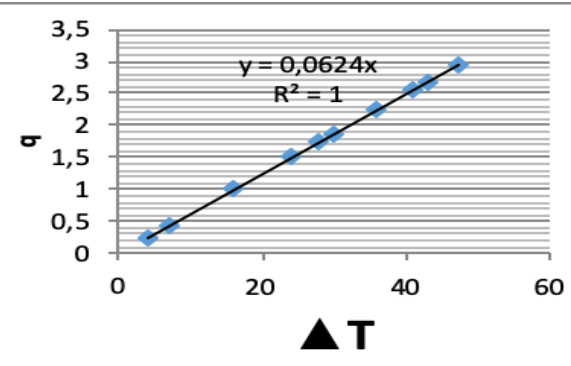

Gambar 12 Hubungan temperatur terhadap kalor

Pada gambar 12 , dapat dilihat $R^{2}=1$, ada hubungan kuat antara $\Delta \mathrm{T}$ atau selisih temperatur terhadap Kalor yang dihasilkan. Semakin naik $\Delta \mathrm{T}$ atau selisih temperatur maka kalor yang dihasilkan juga akan naik.

\section{SIMPULAN}

Dari hasil pengujian yang telah dilakukan selama 10 menit dapat disimpulkan bahwa : Alat ini memberikan manfaat energi panas menjadi listrik dengan kapasitas kecil, maka dibutuhkan perbedaan temperatur yang lebih besar. Dengan hasil $\Delta \mathrm{T}=8 \mathrm{oC}$ dari sumber panas dan element Peltier menghasilkan perpindahan panas $(\mathrm{q})=4992 \mathrm{Watt}$, dan kuat arus listrik $(\mathrm{I})=35,7 \mathrm{~mA}$.

\section{DAFTAR PUSTAKA}

Buchori; Luqman, 2004, Perpindahan Panas (Heat Transfer), Fakultas Teknik, Universitas Diponegoro, Semarang.

Delly; Jenny, Muhammad Hasbi, Indra Fitra Alkhoiron, 2016, Studi Penggunaan
Modul Thermoelektrik Sebagai Sistem Pendingin Portable, ENTHALPY - Jurnal Ilmiah Mahasiswa Teknik Mesin EISSN:2502-8944, Vol. 1, No.1 Mei 2016, Urusan Teknik Mesin Fakultas Teknik Universitas Halu Oleo, Kendari.

F. Keith dan A. Priyono, Prinsip-Prinsip Perpindahan Panas, Edisi 3, Jakarta, Indonesia: Erlangga, 1986.

G. Min, D.M. Roe, Handbook of Thermoelectrics, Peltier devices as Generator, CRC Press LLC,Florida, 1994, p.479.

Halliday; David, Robert Resnick; alih bahasa Pantur Silaban, Erwin Sucipto, 1987, Fisika 1, Erlangga, Jakarta.

Khamid; Mohammad Abdul, 2015. Rancang Bangun Sistem Kendali Suhu dan Kelembaban Pada Prototype Greenhouse Tanaman Kedelai dengan Pemanfaatan Peltier Menggunakan Metode Fuzzy Logic, Skripsi, Fakultas Teknik, Universitar Jember.

Nandy Putra, Raldi Artono Koestor, M. Adhitya, Ardian Roekettino, dan Bay Trianto.2009, Potensi Pembangkit Daya Thermoelectric Untuk Kendaraan Hibrid", Jurnal Makara Teknologi. Vol.13, No.2,.53-58.

Putra; Nandy, Raldi Artono Koestoer, M. Adhitya, Ardian Roekettino, dan Bayu Trianto, 2009, Potensi Pembangkit Daya Termoelektrik Untuk Kendaraan Hibrid, Makara, Teknologi, Vol. 13, No. 2, November 2009: 53-58.

Rahardja, Istianto Budhi.2016. Buku Diktat Perpindahan Panas. Bekasi. Jurusan Teknologi Pengolahan Hasil Perkebunan. Politeknik Kelapa Sawit Citra Widya Edukasi.

Ryanuargo,Syaiful Anwar, dan Sri Poernomo Sari.2013. Generator Mini dengan Prinsip Thermoelektrik dari Uap Panas Kondensor pada Sistem Pendingin.Jurusan Teknik Elektro, Fakultas Teknologi Industri,Universitas Gunadarma.

Salsabiila; Firanda Permata, Muhammad Hijriy Apriansyah, Nabila Rachmatika, Taufik Maulana, Tatun Hayatun Nufus, dan Emir Ridwan, 2016, Konversi Energi Panas Surya menjadi Listrik menggunakan Peltier TEC 1-12706, Prosiding Seminar Nasional Teknik Mesin Politeknik Negeri Jakarta (2019), 194199, ISSN 2085-2762. 